\title{
Erratic migration of Ascaridia hermaphrodita (Nematoda: Ascaridida) in a blue-fronted Amazon parrot (Amazona aestiva) from illegal wildlife trade: case report
}

\author{
[Migração errática de Ascaridia hermaphrodita (Nematoda: Ascaridida) em papagaio-verdadeiro \\ (Amazona aestiva) oriundo do comércio ilegal: relato de caso] \\ R.S. Siqueira ${ }^{1}$, R.B. Lucena ${ }^{2}$, R.R. Guerra ${ }^{3}$, V.L.R. Vilela ${ }^{4}$ R.H. Vasconcelos ${ }^{5}$, \\ A.M.G.G. Quaresma ${ }^{6}$, F. Riet-Correa ${ }^{2}$ \\ ${ }^{1}$ Aluna de pós-graduação - Universidade Federal de Campina Grande - Campina Grande, PB \\ ${ }^{2}$ Universidade Federal de Campina Grande - Campina Grande, PB \\ ${ }^{3}$ Universidade Federal da Paraíba - Areia, PB \\ ${ }^{4}$ Instituto Federal da Paraíba - Sousa, PB \\ ${ }^{5}$ Universidade Federal do Agreste de Pernambuco - Garanhuns, PE \\ ${ }^{6}$ Universidade Trás-os-Montes e Alto Douro, Vila Real, Portugal
}

R.S. Siqueira
https:// https:// R.B. Lucen
https:// hitps.// 0 /0000-0002-2968-5766 R.R. Guerra https://
orcid.org/0000-0001-8226-8606 V.L.R. Vilela https:// orcid.org/0000-0001-9891-7842 R.H. Vasconcelos https://

orcid.org/0000-0002-6069-0053 A.M.G.G. Quaresma https:// /0000-0002-6655-3076 F.Riet-Correa https:// orcid.org/0000-0001-5738-7785

\begin{abstract}
Ascaridiasis by Ascaridia hermaphrodita is a common parasitic disease in blue-fronted Amazon parrots (Amazona aestiva) and the contamination occurs by ingestion of eggs. Illegal trade of wild birds can increase the frequency of visceral erratic migration by this parasite. Hence, this report describes the erratic migration of A. hermaphrodita and associated lesions in a blue-fronted Amazon parrot. This is a retrospective study, which originated from several apprehension of illegal birds in the state of Paraíba, Brazil. Necropsy revealed intense intestinal ascarid infestation. Hepatic lesions were also observed associated with the parasite migration. Stereoscopy allowed the identification of the morphology of the parasites. Summarizing, this condition in wild birds is not fully understood and may be associated with illegal trade.
\end{abstract}

Keywords: anthropic action, wild bird health, psittacine parasitism, unusual visceral migration

\section{RESUMO}

Ascaridíase por Ascaridia hermaphrodita é uma doença parasitária comum em papagaios-verdadeiros. Sua contaminação ocorre pela ingestão de ovos. $O$ tráfico de aves silvestres pode facilitar a migração errática visceral desse parasita. Este relato descreve a migração errática de A. hermaphrodita e lesões associadas em papagaio-verdadeiro. Trata-se de um relato retrospectivo, analisado a partir de uma série de apreensões de aves no estado da Paraíba, Brasil. A necropsia revelou intensa infestação ascarídea intestinal. Também foram observadas lesões hepáticas em uma ave, associadas à migração do parasita. A estereoscopia permitiu distinguir a morfologia dos parasitas. Resumidamente, essa condição em aves silvestres é pouco conhecida e pode ser considerada, inclusive, associada à comercialização ilegal.

Palavras-chave: ação antrópica, saúde aviária silvestre, parasitismo de papagaios, migração visceral incomum

\section{INTRODUCTION}

Ascaridia hermarphrodita is a member of the superfamily Heterakoidea, family Ascaridiidae, such as Ascaridia galli an important helminth that causes morbidity in chickens, turkeys, and geese. This parasite has lateral alae throughout the body, total body length varying from medium to small, and pre-cloacal and post-cloacal suckers with chitinous rims on males. Its cycle is direct: after egg ingestion, hatching occurs in proventriculus or duodenum, and shedding of infecting L2 larvae occur through feces. A histiocytic phase may occur in the intestine with possible erratic

Recebido em 12 de agosto de 2020

Aceito em 13 de janeiro de 2021

E-mail: siqueiraras@gmail.com 
migration (Kajerova et al., 2004; Hodová et al., 2008). There are descriptions of migration in albumen by $A$. galli with deposition of L2 larvae in eggs of layer hens (Bharat et al., 2017); in liver and biliary ducts in natural and experimental conditions by $A$. hermaphrodita and Ascaridia columbae in psittacine and pigeons (Columba livia), respectively, and even cerebrospinal migration by Baylisascaris procyonis in psittacine (Wilson et al., 1999).

Illegal wildlife trade may cause severe damage to the health of wild birds during capture, transportation or distribution of individuals due to the inadequate sanitary conditions that favor the occurrence of several diseases, including parasitic infestations (Melo et al., 2013; Bernadi et al., 2014). Blue-fronted Amazon parrots (Amazona aestiva) are birds from the order Psittaciformes that are frequently traded illegally due to their exuberant colors, size, vocalization ability, wide area of occurrence and ease of capture (Souza and Vilela, 2013). The occurrence of erratic visceral migration by ascarids in psittacine have been reported previously. However, this study aimed to describe this finding in an aggravating anthropic activity, the illegal trade of wild birds.

\section{CASUISTRY}

A retrospective consult to the report files of the Laboratory of Veterinary Pathology of the Federal University of Paraíba (LPV-UFPB), between 2013 and 2014, the Wild Animal Screening Center (CETAS-IBAMA) of Paraíba, Brazil, located in Cabedelo (6 $6^{\circ} 8^{\prime} 49^{\prime \prime} \mathrm{S}$; 34 50 $02^{\prime \prime} \mathrm{W}$ ), received 18 blue-fronted Amazon parrots $(A$. aestiva) that were seized from illegal wildlife trade. There were sixteen females and two males, which were all adults (identified through the observation of gonadal maturity and feathers at necropsy). Individuals presented poor body condition with no history of vaccination, deworming or veterinary care. At seizing, birds were found in small spaces and from different locations, in which they were starving or fed with inadequate diet, and visible external lesions were found, such as abrasions.

Parrots were allocated in CETAS cages, monitored with technical care, microchipped and weighed. However, sudden death occurred, and carcasses were stored in $-10^{\circ} \mathrm{C}$. Then, these were submitted to the LPV-UFPB for necropsy and establishment of causa mortis with protocol 02019.00129/2009 (CETAS-IBAMA) and substantiated by the certificate of the Ethics Committee on the Use of Animals of the Federal University of Campina Grande (CEUA-UFCG), under number 060/2019. At necropsy, sex and gonadal maturity were determined, body condition parameters were determined through evaluation of volume of muscles and fat deposition before and after skin and feathers were removed, in addition to exposure of sternum.

After lesions were observed and registered, organs were collected in $10 \%$ formaldehyde for histopathological processing and/or frozen to investigate other possible etiologies. Parasite specimens were collected fixated in $10 \%$ formaldehyde, and preserved afterwards in AFA solution (alcohol, formaldehyde and acetic acid). Fixated organs were submitted to routine histopathological processing, analyzed under light microscope and cuts were stained with Hematoxylin-Eosin to identify lesions. In cases with parasitic lesions, parasites were identified according to the celomatic muscles, lateral alae, and morphology of intestines and esophagus, and under the diagnostic perspective of at least three pathologists. Following parasite fixation in AFA solution at $65^{\circ} \mathrm{C}$, counting was performed with stereomicroscope and specimens were preserved in alcohol $70 \%$ with lactophenol clarification.

The determined diagnosis for the lot was intense intestinal ascariasis, and intense granulomatous hepatitis in one of the birds. In this case, five to fifteen roundworms were found in sectioned intestinal fragments of approximately fifteen centimeters (Figure 1c). The detection of eggs in direct examination was not possible due to the dryness in the thermal conditioning, only in histopathological evaluation. Birds presented poor body condition (Figure 1a) with loss of muscle mass and exposure of sternum, especially the individual from the report (Figure 1b).

In addition to the intense intestinal infection, macroscopic alterations consisted of hepatomegaly (Figure 1d) and the presence of randomly distributed multifocal yellowish areas, which were coalescent, friable, and uniform after cutting (Figure 1e, 1f). Through stereomicroscopy, the parasite identification was possible only in male parasites due to the unavailability of adequately preserved females, 
and A. hermaphrodita was concluded. This identification was possible with the verification of mouth formed by dorsal and lateroventral papillae in the anterior extremity (Figure 2e) and bulge of the cloacal sucker with chitinous spicules in the posterior end (Figure 2f) (Kajerova et al., 2004; Hodová et al., 2008; Goméz-Puerta et al., 2009).

Erratic migration was observed in histopathology (Figures $2 b, 2 c$ and $2 d$ ), in which parasitic round structures that were sectioned transversally were observed in hepatic parenchyma or inside blood vessels, which were often associated with mixed inflammatory infiltrates and fibrosis. The presence of discrete lateral alae, moderate celomatic muscles linked to lateral cords, broad esophagus and intestines with thin layers and cubic cells pointed to ascarid larvae (Gardiner and Poynton, 1999). Exceptionally adhered to the esophagus mucosa, the presence of an egg characterized by oval shape with thick shell and uninuclear zygote inside (Figure 2d) was observed, which may be suggested as the ingestion by the host during the direct cycle.
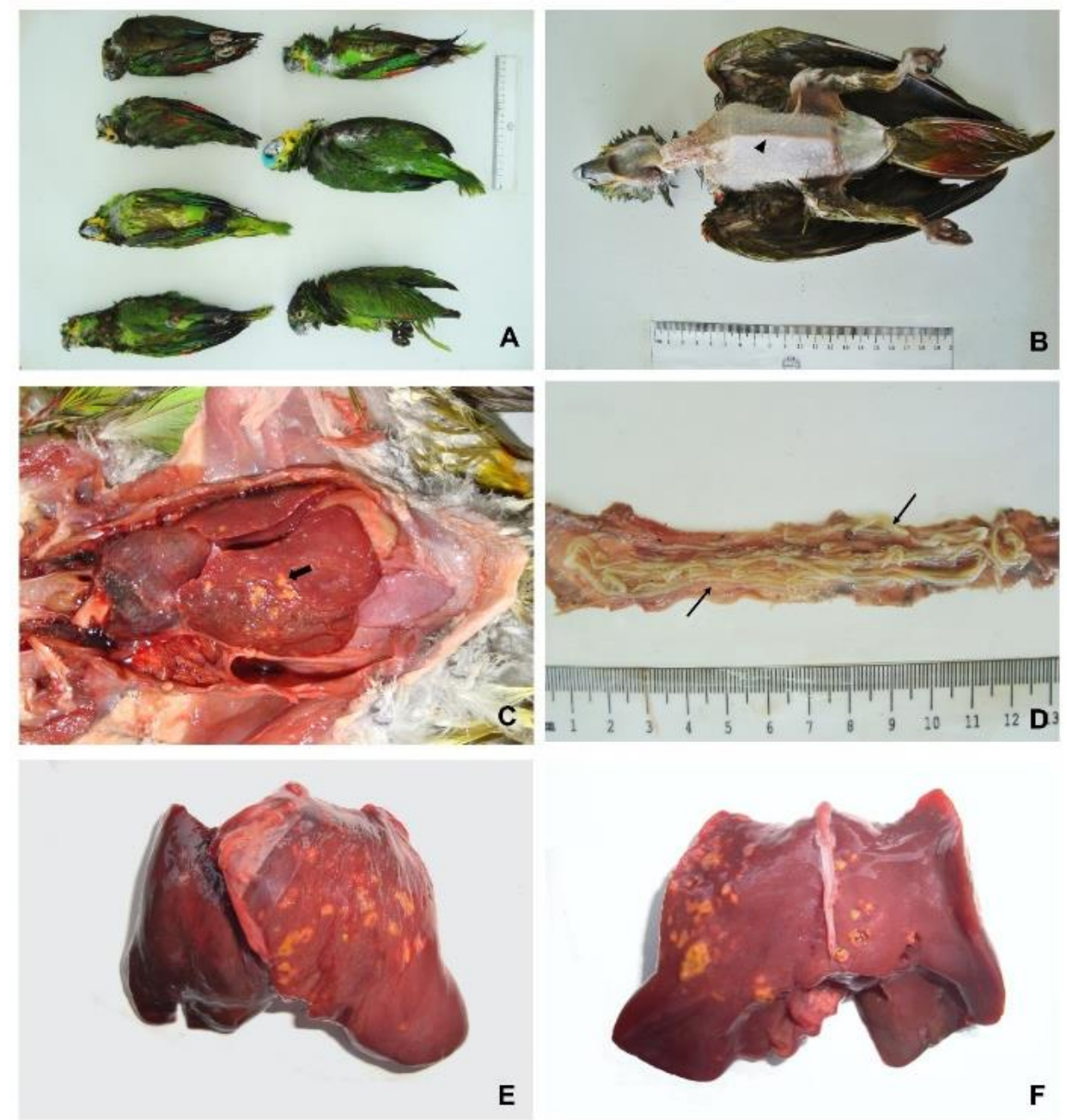

Figure 1. Photographic images of clinical-pathological aspects of intense infestation by Ascaridia hermaphrodita in blue-fronted Amazon parrots (Amazona aestiva). a) Specimens of A. aestiva with cachexic body condition. b) Bird from the report exhibiting atrophy of pectoral muscles and exposure of sternum (arrowhead). c) Hepatomegaly and multifocal granulomatous hepatitis (thick arrow). d) Small intestine: presence of numerous ascarids (slim arrow) with results ranging from 5 to 15 specimens. e) and f) Liver, cranial and visceral views, respectively, with multifocal and coalescent yellowish areas, which were friable and randomly distributed. 

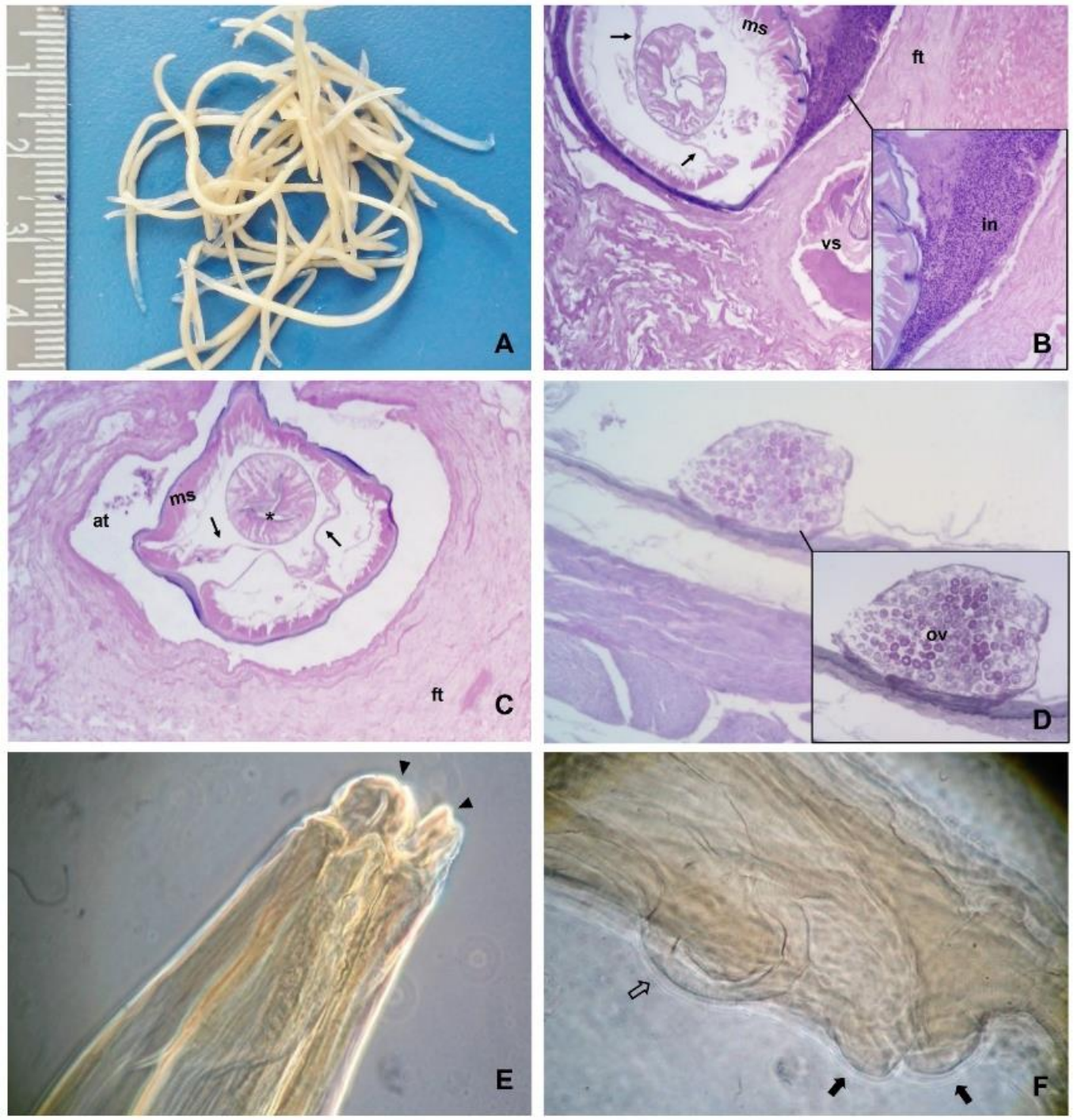

Figure 2. Macroscopic, stereomicroscopic and histological images of A. hermaphrodita in intense infestation of blue-fronted Amazon parrot (A. aestiva). a) Specimens of A. hermaphrodita after fixation in Alcohol-Formaldehyde-acid acetic solution (AFA). b) and c) Liver: foci with transversally sectioned parasitic round structures composed of discrete lateral alae, lateral cords (thin arrow) linked to celomatic muscles (ms), esophagus and intestines formed by a single layer (asterisk) of cuboidal cells, involved by fibrous tissue (ft) involving periportal vasa (vs), arterioles (at) and moderate mixed inflammation (in). d) esophagus with oval structure (ov) adhered to the mucosa filled by a single zygote covered with thick layer. e) and f) Anterior and posterior extremities, respectively, of male A. hermaphrodita exhibiting mouth with dorsal and lateroventral papillae (arrowhead), cloacal sucker bulge (unfilled arrow) and chitinous distal spicules (filled arrow).

\section{DISCUSSION}

In its habitual pathogeny, light infestations of $A$. hermaphrodita cause intestinal malabsorption and diarrhea. However, it may cause ulcers and even intussusception in severe infestations (GonzálezAcuña et al., 2007). The uncommon occurrence of severe erratic migration was previously described in experimental or natural conditions in pet psittacine (Wilson et al., 1999). The blue-fronted Amazon parrot species was reported as a frequent host of $A$. hermaphrodita, especially in conditions where captive superpopulations with access to dirt are submitted to malnutrition without deworming. 
These are common conditions to which illegally traded wild birds are exposed in Brazil (Kajerova et al., 2004; Melo et al., 2013; Souza and Vilela, 2013).

Other ascarids, such as Ascaridia platyceri and $A$. columbae also produce similar lesions in different psittacine traded in legal conditions, such as severe cachexia, ascites, intestinal inflammation, congestion and obstruction, in addition to hepatic adherence or necrosis (Gonzaléz-Hein et al., 2012; Bernadi et al., 2014). Therefore, stereoscopy provide the means for differentiation of the distal extremity morphology of males. In $A$. hermaphrodita, a pair of cuticular alae form a soft canal, and lateral serration is observed in $A$. platyceri (Kajerova et al., 2004; Hodová et al., 2008).

For the diagnosis of ascariasis in parrots, clinical signs include ataxia, aqueous feces, and cachexia. Treatment should focus on re-establishing conditions of hydration with crystalloid fluids, microbiota and nutritional status with probiotics, and elimination of adult parasites with deworming. Radiographic examination of bluefronted Amazon parrot infested with $A$. hermaphrodita was useful in revealing proventriculus with distention and impaction with dense material of mineral to metallic opacity, and dislocation of gizzard (Wilson et al., 1999), suggesting intense ascariasis.

Hepatic granulomas were expressive lesions in this case and are occasionally described in the diagnosis of ascariasis of parrots. However, these findings are commonly attributed to colibacillosis, chlamydiosis and aspergillosis, in which histopathological evaluation and complementary exams are important to the differential diagnosis (Supartika et al., 2006). Free-living birds may host parasites in symbiosis without clinical signs. However, the deplorable propaedeutic and management conditions in illegal trade, in addition to the different origins of birds, allow the shedding of pathogenic agents in reduced space. The lack of deworming and crossed exposure to feces potentiates the clinical severity of these diseases (Melo et al., 2013; Souza and Vilela, 2013; Bernadi et al., 2014).

\section{CONCLUSION}

The illegal trade of wild birds in Brazil aggravates sanitary conditions that are simple to resolve. The intense infestation and erratic migration of $A$. hermaphrodita in blue-fronted Amazon parrots in Paraíba State may occur through the diverse anthropic actions that affect the native avifauna. For the etiological diagnosis of this condition, parasitological examination by stereomicroscopy and histopathology are both useful in the morphological definition of the parasite, especially when used in combination.

\section{REFERENCES}

BERNADI, B.; FICHI, G.; FINOTELLO, R.; PERUCCI, S. Internal and external parasitic infections in captive psittacine birds. Vet. Rec., v.174, p.69, 2014.

BHARAT, G.A.; KUMAR, N.P.; SUBHASISH, B.; RIA, B. A report of Ascaridia galli in commercial poultry egg from Índia. J. World Poult. Res., v.7, p.23-26, 2017.

GARDINER, C.H.; POYNTON, S.L. An atlas of metazoan parasites in animal tissues. American Registry of Pathoplogy. Washington: Armed Forces Institute Pathololy, 1999. p.19-21.

GÓMEZ-PUERTA, L.A.; LÓPEZ-URBINA, M.T.; GONZÁLEZ, A.E. Ocurrencia de Ascaridia hermaphrodita (Nematode: Ascaridiidae) em el loro de Cabeza Azúl (Pionus menstruus) em Perú. Peruvian J. Biol., v.15, p.133-135, 2009.

GONZÁLEZ-ACUÑA, D.; FABRY, M.; NASCIMENTO, A.A.; TEBALDI, J.H. Death of two slender-billed parakeet (King) (Enicognathus leptorhynchus) (Aves, Psittacidae) by Ascaridia hermaphrodita (Froelich, 1789, Railliet \& Henry, 1914) at the National Zoo of Santiago, Chile. Braz. J. Vet. Anim. Sci., v.59, p.539-540, 2007.

GONZALÉZ-HEIN. G.; FREDES, F.; KINSELLA, M. et al. New reports of helminthes in captive exotic psittacine birds in Chile. Arch. Med. Vet., v.44, p.87-91, 2012.

HODOVÁ, I.; BARUS, V.; TUKAC, V. Note na morphology of two nematode species Ascaridia hermaphrodita and Ascaridia platyceri (Nematoda): scanning electron microscope study. Helminthologia, v.43, p.109-113, 2008. 
KAJEROVA, V.; BARUS, V.; LITERAK, I. Nematodes from the genus Ascaridia parasitizing psittaciform birds: a review and determination key. Vet. Med. Czech, v.49, p.217-223, 2004.

MELO, C.M.F.; OLIVEIRA, J.B.; FEITOSA, T.F. et al. Parasites of psittaciformes and accipitriformes in Paraíba state, Northeastern Brazilian. Braz. J. Vet. Parasitol., v.22, p.314$317,2013$.

SOUZA, T.O.; VILELA, D.A.R. Espécies ameaçadas de extinção vítimas do tráfico e criação ilegal de animais silvestres. Atual. Ornitol., v.176, p.64-68, 2013.
SUPARTIKA, I.K.E.; TOUSSAINT, M.J.M.; GRUYS, E. Avian hepatic granuloma. A review. Vet. Q., v.28, p.82-89, 2006.

WILSON, G.H.; GREENACRE, C.B.; HOWERTH, E.W. et al. Ascaridiosis in a group of psittacine birds. J. Avian Med. Surg., v.13, p.32-39, 1999. 